\title{
BIOLOGICAL PRODUCTIVITY OF OLIGOTROPHIC AND EUTROPHIC PEATLANDS IN SOUTHERN TAIGA IN WESTERN SIBERIA
}

\author{
Golovatskaya E.A.
}

\author{
Institute of monitoring of climatic and ecological systems $S B R A S$, Tomsk
}

golovatskaya@imces.ru

\begin{abstract}
The results of long-term (1999-2006) investigations of dynamics of vegetation storages, phytomass growth, dead matter, and net primary productivity (NPP) at oligotrophic and eutrophic peatlands in southern taiga in Western Siberia (Tomsk region) are presented. The storages of phytomass at different ecosystems of oligotrophic bog have similar values. Storages of phytomass at eutrophic peatland are 2 times higher in comparison to oligotrophic bog. The qualitative composition of phytomass depends on vegetation of the studied ecosystems, nutrient availability and hydrothermal conditions.
\end{abstract}

Key words: peatlands, biological productivity, net primary production.

\section{INTRODUCTION}

Peatland ecosystems play an important role in the biosphere. Peatlands occupy only about $3-5 \%$ of the terrestrial surface, but the global peat resources are estimated at 120 - 455 PgC [Gorham, 1991; Vomperskii, 1994]. Vomperskii et al. (1999) estimated the total area of peaty soils of Russia to be 369 million ha (about $22 \%$ of the country area). Peatlands (peaty soils with peat layer more than $30 \mathrm{~cm}$ ) occupies 139 million ha. Peatlands of Russia contain 100.9 billion tons of carbon. About 12.6 billion tons of carbon stored in shallow peaty soils. According to other sources carbon deposits in peatlands of Russia varies from 116.5-118.9 billion tons [Birukova, Orlov, 1996; Efremov et al., 1994] to $215 \mathrm{PgC}$ [Botch et al., 1995]. The area of peatlands in Western Siberia is about $42 \%$ of the area of Russian peatlands. Peatlands of West Siberia contain 42.3 billion tons of carbon and 36\% of the Russia peat stock [Efremov et al., 1994]. Carbon content in Western Siberia peatlands varies from $55 \mathrm{Pg}$ [Efremov, Efremova, 2007] to $70 \mathrm{Pg}$ [Sheng et al., 2004]. Although the size of the carbon reservoir is considerable, the role of peatlands in the global carbon budget is not investigated deep enough.The biological productivity is the ability of living organisms to create, preserve and transform organic matter. Value of productivity depends on species composition in ecosystem, climatic and hydrothermal conditions. Forest, forest-grass, grass-mossy and mossy associations are formed depending on dynamics of the water regime. Biological productivity can be characterized by quantity of biomass at a certain place in a certain time or amount of plants growth (net primary production - NPP) [Chramov, Valutskii, 1977]. The total biomass consist the next parts: photosynthetic phytomass (green part of mosses, live leafs of shrubs, green herbs); nonphotosynthetic phytomass (nonchlorophyllic alive stems and tillering zones of herbs, stem of shrubs, and alive roots of plants); dead plant material (remains of mosses, herbs, and shrubs). Until the recent times there were only a few studies of biological productivity of native peatland ecosystems. NPP of peatland ecosystems is sensitive to both hydrology and temperature [Billings et al., 1982; Kim, Verma, 1992; Moore, Knowles, 1989; Moore et al.,2002; Silvola et al., 1996] and, therefore to climate changes. While NPP is difficult to measure, there are several examples of direct measurements of net ecosystem exchange (NEE: $\mathrm{CO}_{2}$ uptake minus respiration), though only for part of the year [Carroll, Crill, 1997; Klinger et al., 1994; Neumann et al., 1994; Szumigalski, Bayley, 1997].

The aim of this study was to estimate biological productivity for oligotrophic and eutrophic peatlands in the southern.

\section{STUDY AREA}

The region chosen for study of biological productivity is located between the Iksa and Bakchar rivers $\left(56^{\circ} 58^{`} \mathrm{~N} 82^{\circ} 36^{`} \mathrm{E}\right)$ at the Bakcharskoe bog (area $1400 \mathrm{~km}^{2}$ ). The studied area (see Fig.1) includes the following ecosystems: pine- shrub-sphagnum (PSS) community, a similar community with stunted (low) pine trees (LPSS), and sedge-sphagnum fen (SSF). Typical plant and moss species of these communities are listed in Table 1. A detailed description of the vegetation at the studied plant communities is presented in [Golovatskaya, Porokhina, 2005]. The observation points are characterized by different water table levels and different hydrological regimes. The observation points are located $7 \mathrm{~km}$ away from the nearest small settlement, and 200 $\mathrm{km}$ away from the nearest town and have not been subjected to any anthropogenic impact in the past. The peat deposit is $1-3 \mathrm{~m}$ thick and 3-5 ka old [The Great Vasyugan Bog..., 2002]. 
The biological productivity at eutrophic fen (EF) "Samara" was studied too. The peatland has square 400 ha and located at low left terrace of Bakchar river (Table 1). Latin names of the vascular plants are given on [Cherepanov, 1995], mosses on [Ignatov, Afonina, 1992]. Maximum depth of peat is $4 \mathrm{~m}$.

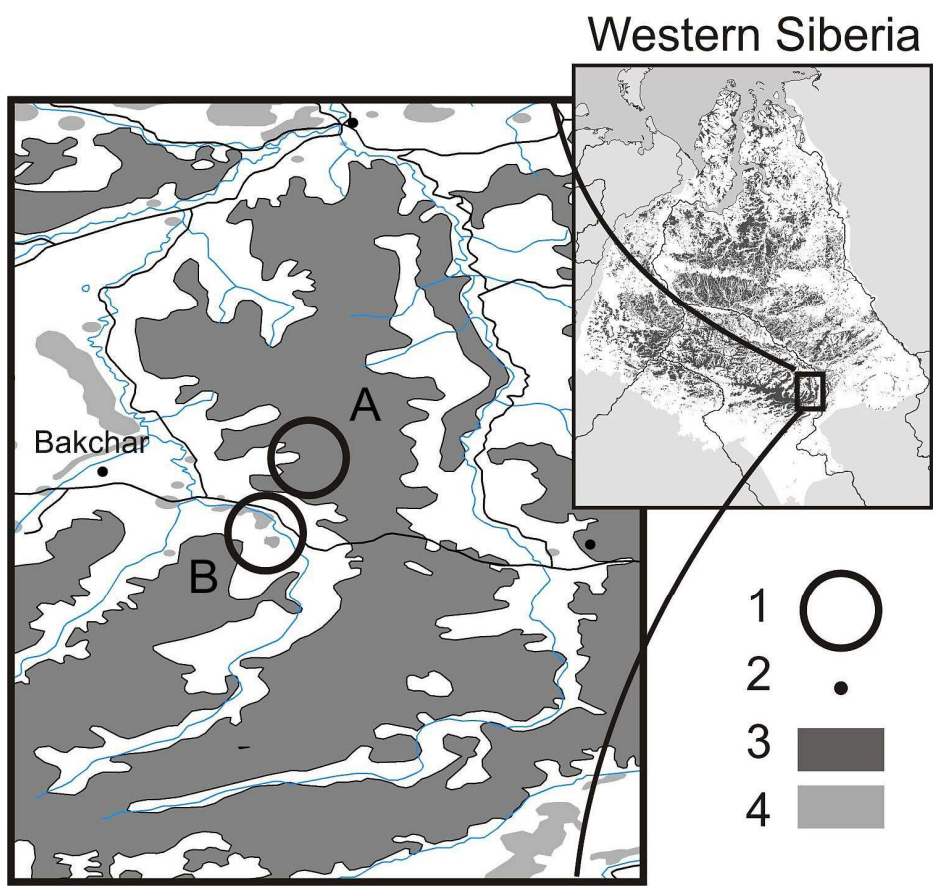

Fig.1. The study area. 1 - Observation points, 2 settlements, 3 - Great Vasyugan Mires, 4 - peatlands, A - oligotrophic observation sites. B - eutrophic observation sites.

Puc.1. Область исследования. 1 - точки наблюдений, 2 - населенные пункты, 3 - Большое Васюганское болото, 4 - болота. А - пункты наблюдений на олиготрофном болоте, В - пункты наблюдений на эвтрофном болоте.

Table 1. Vegetation covers at studied peatlands. Numbers in brackets are projective cover area in $\%$.

Таблица 1. Характеристика растительного покрова исследуемых болотных экосистем (в скобках проективное покрытие, \%).

\begin{tabular}{|c|c|c|c|}
\hline Trees & Shrubs & Herbs & Mosses \\
\hline \multicolumn{4}{|c|}{$\begin{array}{l}\text { PSS - Pine-Shrub-Sphagnum community. } \\
\text { Peat deposit depth } 100 \mathrm{~cm},(\text { WTL }(\mathrm{cm}) \text { mean: }-23, \text { max: }+2, \text { min: }-71)\end{array}$} \\
\hline $\begin{array}{l}\text { Pinus silvestris L. } \\
\text { Pinus sibirica Du Tour } \\
\text { Betula pubescens Ecrh. } \\
(90 \%)\end{array}$ & $\begin{array}{l}\text { Ledum palustreL. } \\
\text { Chamaedaphne calyculata (L.) Moench } \\
\text { Vaccinium vitis-idaea } L . \\
\text { Vaccinium oxycoccos } L . \\
(80 \%)\end{array}$ & $\begin{array}{l}\text { Carex globularis } L . \\
\text { Eriophorum vaginatum } L . \\
\text { Rubus chamaemorusL. } \\
(15 \%)\end{array}$ & Sphagnum angustifolium (Russ.)C.Jens. \\
\hline \multicolumn{4}{|c|}{$\begin{array}{l}\text { LPSS - Low Pine-Shrub-Sphagnum community. } \\
\text { Peat deposit depth } 300 \mathrm{~cm},(\text { WTL }(\mathrm{cm}) \text { mean: }-10, \text { max: }+8, \text { min: }-31)\end{array}$} \\
\hline $\begin{array}{l}\text { Pinus silvestris } \\
\text { f. Litwinowii } \\
(30 \%)\end{array}$ & $\begin{array}{l}\text { Ledum palustre } L . \\
\text { Chamaedaphne calyculata } L . \\
\text { Andromeda polifolia } L . \\
\text { Vaccinium uliginosum } L . \\
(65 \%)\end{array}$ & $\begin{array}{l}\text { Eriophorum vaginatum } L \text {. } \\
\text { Rubus chamaemorus } L . \\
\text { Drosera rotundifolia } L . \\
(5 \%)\end{array}$ & $\begin{array}{l}\text { Sphagnum fuscum (Schimp. )Klinggr. } \\
\text { Sph. angustifolium(Russ.)C.Jens. } \\
\text { Sph. magellanicum Brid. } \\
(95 \%)\end{array}$ \\
\hline \multicolumn{4}{|c|}{$\begin{array}{l}\text { SSF - Sedge-Sphagnum fen. } \\
\text { Peat deposit depth } 250 \mathrm{~cm},(\text { WTL }(\mathrm{cm}) \text { mean: }-5, \text { max: }+6 \text {, min: }-16)\end{array}$} \\
\hline- & $\begin{array}{l}\text { Chamaedaphne calyculata } L . \\
\text { Andromeda polifolia } L . \\
\text { Vaccinium oxycoccus } L \text {. } \\
(20 \%)\end{array}$ & $\begin{array}{l}\text { Eriophorum vaginatum } L . \\
\text { Carex rostrata Stokes. } \\
\text { Carex limosa L. } \\
\text { Scheuchzeria palustris } L . \\
(50 \%)\end{array}$ & $\begin{array}{l}\text { Sphagnum fuscum (Schimp. )Klinggr. } \\
\text { Sph. angustifolium(Russ.)C.Jens. } \\
\text { Sph. magellanicum Brid. } \\
(100 \%)\end{array}$ \\
\hline \multicolumn{4}{|c|}{$\begin{array}{l}\text { EF - eutrophic fen Samara } \\
\text { Peat deposit depth } 400 \mathrm{~cm},(\text { WTL }(\mathrm{cm}) \text { mean: }-5, \text { max: }+10, \text { min: }-10)\end{array}$} \\
\hline $\begin{array}{l}\text { Pinus silvestris } L ., \\
\text { Betula pubescens Ecrh. } \\
\text { Salix cinerea L., } \\
\text { S. rosmarinifolia L., } \\
\text { S. pentandra L. }\end{array}$ & $\begin{array}{l}\text { Betula nana } L . \\
\text { Oxicoccus palustris } L .\end{array}$ & $\begin{array}{l}\text { Carex limosa L., } \\
\text { C. diandra Schrank, } \\
\text { Comarum palustre L. }\end{array}$ & $\begin{array}{l}\text { Tomenthypnum nitens (Hedw.) Loeske } \\
\text { Aulacomnium palustre (Hedw.) } \\
\text { Schwaegr. } \\
\text { Helodium blandowii (Web et } \\
\text { Mohr)Warnst. } \\
\text { Drepanocladus aduncus } \\
\text { (Hedw.)Warnst. } \\
\text { Brachythecium mildeanum (Schimp.) } \\
\text { Schimp. } \\
\text { Sphagnum warnstorfii Russ., } \\
\text { Brium pseudotriquetrum (Hedw.) } \\
\text { Schwaegr. } \\
\text { (40\%) }\end{array}$ \\
\hline
\end{tabular}




\section{METHODS}

The above-ground biomass was measured by clipping $0,25 \mathrm{~m}^{2}$ quadrates (three to five per site). Clipped plants were grouped according to their species and divided into living and dead biomass. The total dead biomass consists of litter and dead parts of mosses. Live biomass consists of annual, and perennial photosynthetic biomass (shrub leaves, green parts of herbs and mosses), and nonphotosynthetic biomass (steam shrubs, roots of herbs and shrubs). Below the surface (below moss capitulums) some amount of green parts of mosses exists. We consider these parts belonging to living biomass. Depending on the ecosystem the "green moss layer" varies from 2-3 $\mathrm{cm}$ at LPSS to 5-7 $\mathrm{cm}$ at PSS and up to $15 \mathrm{~cm}$ at SSF. A layer with 20-cm thickness, located deeper the green mosses, was considered to be related to dead part of mosses. This layer was used for below ground phytomass estimation. It is composed of dead, but weakly decomposed moss stems, leaves, dead or live roots of vascular plants.

The below-ground biomass was determined by the excavation of $10 \times 10 \mathrm{~cm}$ pits at each quadrate. Live plant roots were separated from dead mosses in below-ground samples. Samples were oven-dried at $80{ }^{\circ} \mathrm{C}$ till the constant weight. Seasonal dynamics growth was established by weighing the green parts of plants and mosses of the current year. The amount of total biomass was determined at the period of maximum vegetation development (in the end of July - the beginning of August). Litter, above and below-ground biomass was determined each month from May till October at each mire site.

Above-ground production (ANP) of herbs was taken as equal to maximal storage of green phytomass. The production of deciduous shrubs was calculated as a sum of the seasonal maximum of green leaves and young shoots of the current year, production of evergreen shrubs - sum of the maximal phytomass of the current shoots and their leaves. We estimate the production of sphagnum mosses as a difference between seasonal maximum and minimum of green phytomass. ANP was calculated as a sum of production of herbs, shrubs and mosses. Below-ground production (BNP) was calculated as a difference between seasonal maximum and minimum of live roots of shrubs and herbs. The net primary production (NPP) was calculated as a sum of values aboveground and below-ground production [Titlyanova, 1988].

Meteorological observations of air temperature, air humidity, precipitation, water table level, peat moisture were conducted too.

\section{RESULTS AND DISCUSSION}

\section{Phytomass (above and below ground living plant biomass)}

Amount of phytomass is one of the principal characteristic of the biological productivity. The maximum of phytomass storages was observed at the eutrophic peatland. Oligotrophic peatlands have maximal phytomass at PSS, and minimal at SSF.

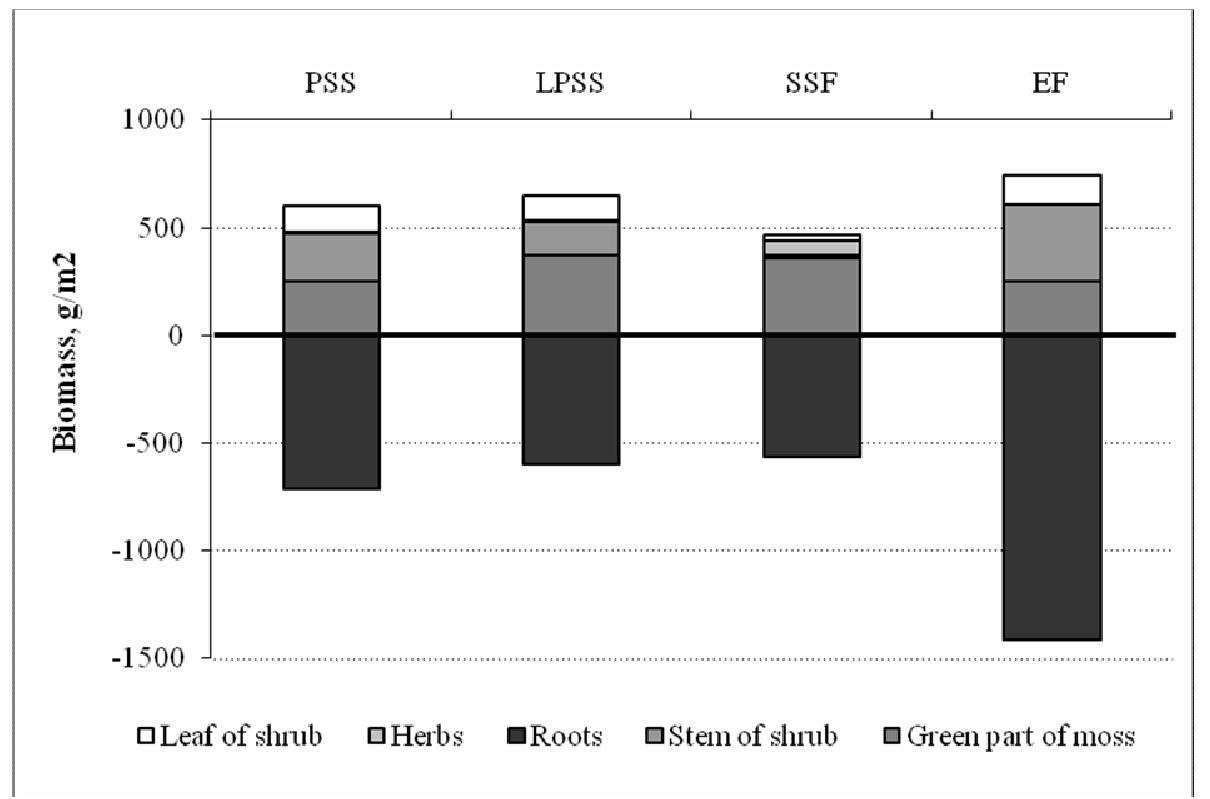

Fig. 2. Structure of aboveground and belowground live phytomass at oligotrophic and eutrophic peatlands.

Puc.2. Структура надземной и подземной живой фитомассы олиготрофных и эвтрофных болотных экосистем.

Total phytomass is controlled by the vegetation type. The average storages of phytomass have similar values in different ecosystems. However the structure of phytomass is differ significantly. Part of herbs in 
vegetation of tall and low ryam is negligibly small, but at SSF and EF the contribution of herbs is about 8 and $35 \%$ accordingly. Shrubs are almost absent at SSF, it resulting in low values of leaf and stem of shrubs storages (Fig. 2).

Vegetation cover of EF consists of high amount of shrubs (Betula nana). Roots of herbs and shrubs have the maximal contribution (55-69\%) to the total phytomass storages at all peatlands. Green parts of mosses (from $12 \%$ on EF to $40 \%$ on SSF), and aboveground parts of shrubs (from 23 to $28 \%$, excluding SSF) gives high contribution to phytomass.

Photosynthetic active phytomass storages depend on the structure of vegetation, but all ecosystems have common regularities. Green parts of mosses $(55 \%-78 \%)$ have the maximum contribution. Part of shrub leafs is rather high $(24 \%-31 \%)$.

It should be noted that maximum input to the total storages of the biomass at all studied peatlands have the dead biomass. It has more than $62 \%$ from the total biomass at EF, and about $75 \%$ at LPSS (Fig.3). The main part of dead biomass is presented by dead parts of mosses. Dead biomass was accounted in upper $20 \mathrm{~cm}$ of peat deposit. The amount of moss remains depends on the density of upper layers of peat deposit, so minimal storages were observes in SSF, where mosses have the loosest structure. Dead mosses amounts at PSS and LPSS and EF has comparable values.

Dead parts of mosses characterize storages of the dead biomass which was accumulated during many years. The following estimations of dead biomass are given only for litter and dead parts of herbs, which characterize annual vegetation dying-off. The amount of litter and dead herbs at PPS and LPSS are practically equal. LPSS and PSS are characterized by the presence of well developed shrub layer, which is the main supplier of the dead biomass. Shrubs are absent at SSF, and the projective cover of sedges is about $50 \%$, it gives the strong income of litter and dead herbs.

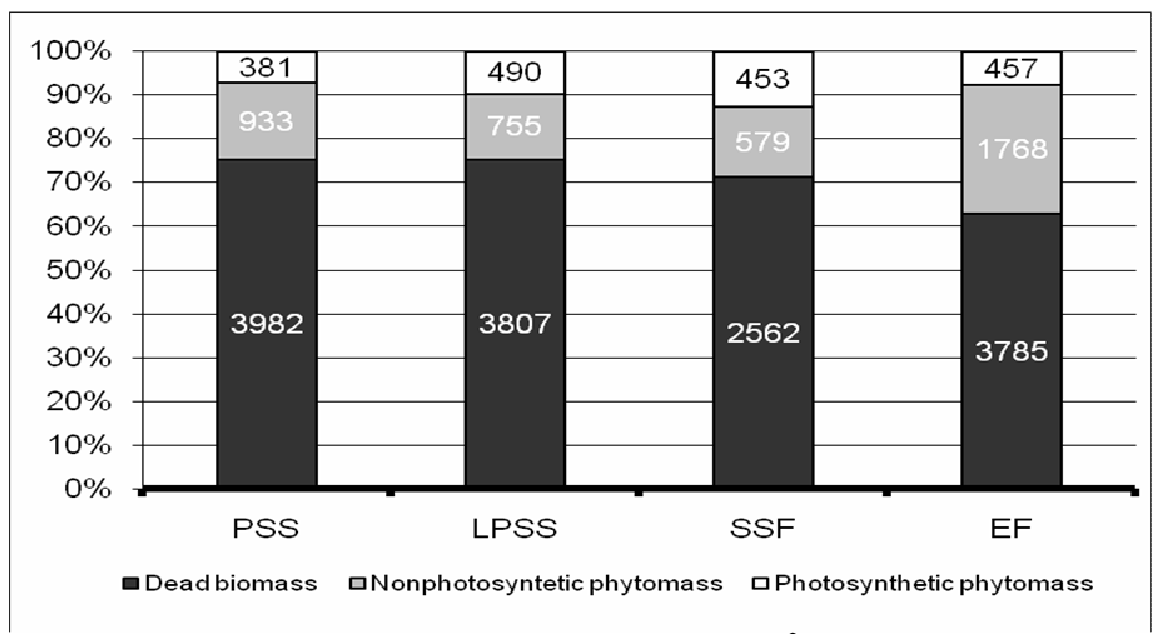

Fig.3. Total biomass structure in different ecosystems (numbers are given in $\mathrm{g} / \mathrm{m}^{2}$ ).

Puc.3. Структура запасов общей биомассы (фитомассы и мортмассы) в разных болотных экосистемах (цифры в столбиках $\left.-\Gamma / \mathrm{M}^{2}\right)$.

Estimation of the biomass reserves describes the basic regularities of the distribution of biomass storages on different ecosystems depending on the composition of vegetation.

Obtained data are corresponds to the data for Western Siberian peatlands received by other author. According to studies of [Valutskii, Chramov, 1976] and [P'yavchenko, 1967] reserves of phytomass at Vasyugan bog varies from 1900 to $17100 \mathrm{~g} / \mathrm{m}^{2}$ depending on the bog type. Efremova T.T. et al. [Efremova, Efremov, 1994] estimates the total storages of vegetation in upper layer of oligotrophic bogs in West Siberia from 2300 to 3100 $\mathrm{g} / \mathrm{m}^{2}$ depending on the micro relief form.

\section{Dynamics of phytomass and dead biomass changes}

The average dynamics of growth increment is expressed by unimodal curve with maximum in July or August. The EF has maximal growth values, and SSF have minimal ones. The phytomass growth at PSS and SSF has the maximum in August. The maximal growth at LPSS and EF was observed in July. The reduction of the growth occurs in September. This reduction is most clearly defined at eutrophic peatland. The basic EF vegetation is presented by deciduous shrubs and herbs.

The growth of phytomass includes growth of herbs, shrubs and mosses (Fig.4). The part of herbs in the total phytomass growth is about $1 \%$ at PSS and LPSS, and $13 \%$ at SSF. The part of shrubs is rather high and 
reaches 57 and $60 \%$ at PSS and EF. Contribution of the shrubs growth to the total growth at SSF is less than $10 \%$. Mosses have the high part in phytomass growth. It changes from $30 \%$ at EF to $77 \%$ at SSF.

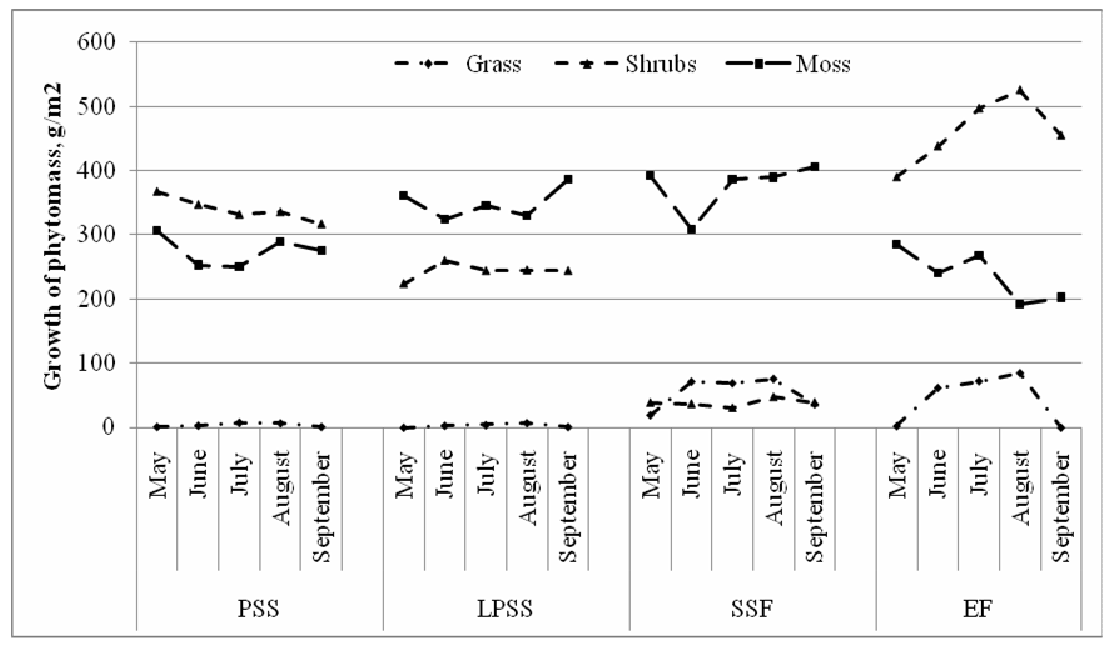

Fig.4. Dynamics of phytomass growth.

Puc.4. Динамика запасов биомассы.

The dynamics of litter and dead parts of herbs is typical for the peatland ecosystems. Maximal values of litter storages were observed in spring and autumn. Summer months are characterized by low values of litter storages. The spring maximum of litter amount exists due to presence of remains of plans falling under the action of snow, wind and low temperatures in winter in addition to plants died in autumn, but does not decomposed during winter. Low values of litter storages are typical for SSF, due to absence of shrubs which construct the main part of litter. Dead biomass at SSF is mainly formed by dead herbs.

The analysis of data has shown that amount of litter and dead herbs is not always depends on the amount of the growth. But litter and dead herbs has the closest relations. According to results of the correlation analysis the strong relationship between amount of litter and dead herbs was revealed for all studied ecosystems. Correlation coefficients vary from 0.38 for LPSS to 0.90 for EF. The strong negative correlation exists between growth of phytomass and litter at EF. It can be explained by the composition and phenological features of the vegetation.

We have found significant negative correlation between phytomass growth and amount of dead herbs. Dynamics of dead herbs and phytomass are exists in antiphase during vegetation period, so minimum amount of dead herbs observed at maximal growth of phytomass. Direct dependences between amounts of litter and growth of phytomass were discovered only for EF.

The dynamics of phytomass growth changes depending on the weather conditions in different years. For example, after rapid begin of growing season in May exists some reduction of the growing rates of plants caused by overweening, heavy rains, or droughts. We perform correlation analysis to reveal meteorological parameters (such as hydrothermal coefficient (HTC), air temperature, precipitation and water table level (WTL)) influencing the dynamics of plants growth.

Table 2. Correlation coefficients between meteorological parameters and growth phytomass.

Таблица 2. Коэффициенты корреляции между метеорологическими параметрами и динамикой запасов фитомассы.

\begin{tabular}{|c|c|c|c|}
\hline & Precipitation & Air temperature & Water table level \\
\hline $\begin{array}{c}\text { PSS } \\
\text { Herbs }\end{array}$ & - & - & -0.69 \\
\hline $\begin{array}{c}\text { LPSS } \\
\text { Herbs }\end{array}$ & 0.45 & - & - \\
\hline $\begin{array}{c}\text { SSF } \\
\text { Herbs }\end{array}$ & - & 0.59 & - \\
\hline $\begin{array}{c}\text { EF } \\
\text { Herbs }\end{array}$ & 0.51 & 0.75 & - \\
\hline $\begin{array}{c}\text { EF } \\
\text { Shrubs }\end{array}$ & 0.47 & - & -0.70 \\
\hline
\end{tabular}

The results of analysis have shown that the total annual growth in oligotrophic bogs does not depend on weather conditions (Table 2). Analysis for each vegetation fraction have shown that growth of herbs at LPSS depends on precipitation (correlation coefficient $r=0.45)$ and HTC $(r=0.53)$. The growth of herbs at SSF depends 
on the air temperature $(\mathrm{r}=0.59)$. The growth of herbs and shrubs at $\mathrm{EF}$ correlated with precipitation $(\mathrm{r}=0.51$ and 0.47 accordingly), and, herbs growth depends on air temperature $(\mathrm{r}=0.75)$.

Results of correlation analysis has shown the negative influence of WTL on growth of shrubs at EF $(r=-$ $0.70)$ and growth of herbs at PSS $(r=-0.69)$.

\section{Net primary production}

The net primary production (NPP) is the accumulation of carbon in the form of vegetation matter. The results of the study have shown that, despite of essential differences in composition of the vegetation, the average values are similar at oligotrophic bogs. NPP for PSS, LPSS and SSF are equal to $558,587,571 \mathrm{~g} / \mathrm{m}^{2}$ per year. NPP at EF is 1.4 times higher in comparison to oligotrophic bogs (Fig.5).

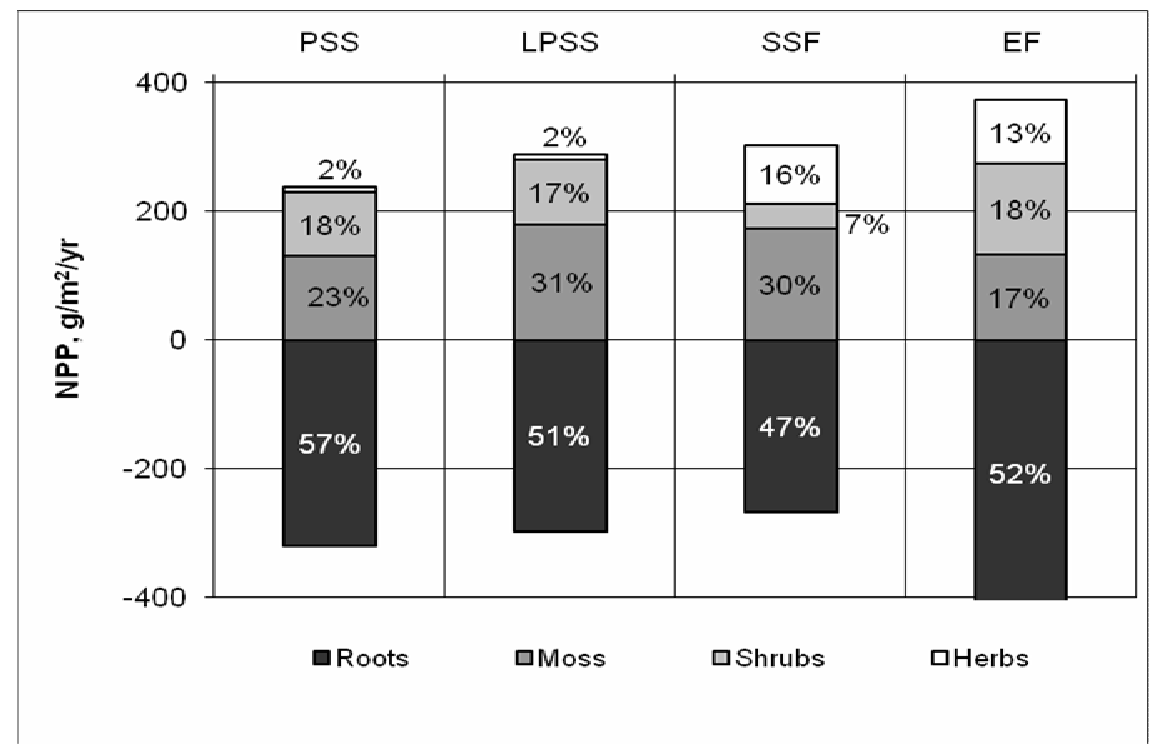

Fig.5. Net primary production at the studied ecosystems.

Puc.5. Чистая первичная продукция исследуемых болотных экосистем.

The main contribution to production at studied oligotrophic ecosystems gives roots of herbs and shrubs (47-57\%) and Sphagnum mosses (23-37\%). Parts of shrubs at PSS and LPSS consist 18 and 17\% accordingly. The contribution of grassy vegetation is more significant at SSF (16\%) but part of shrubs is about $7 \%$.

The qualitative composition of NPP at EF is differs from composition at oligotrophic bog. The main contributions to production give roots of shrubs and herbs (52\%), but part of mosses is equal to $17 \%$. It should be noted, that moss cover at EF is spottiness and sphagnum grows only at hummocks which cover about $40 \%$ of the peatland.

The dynamics of productivity is characterized by reduction of production at all peatlands to 2002 and maximal NPP in 2003, with the exception of EF, where maximum of production was observed in 2005-2006 (Fig. 6).

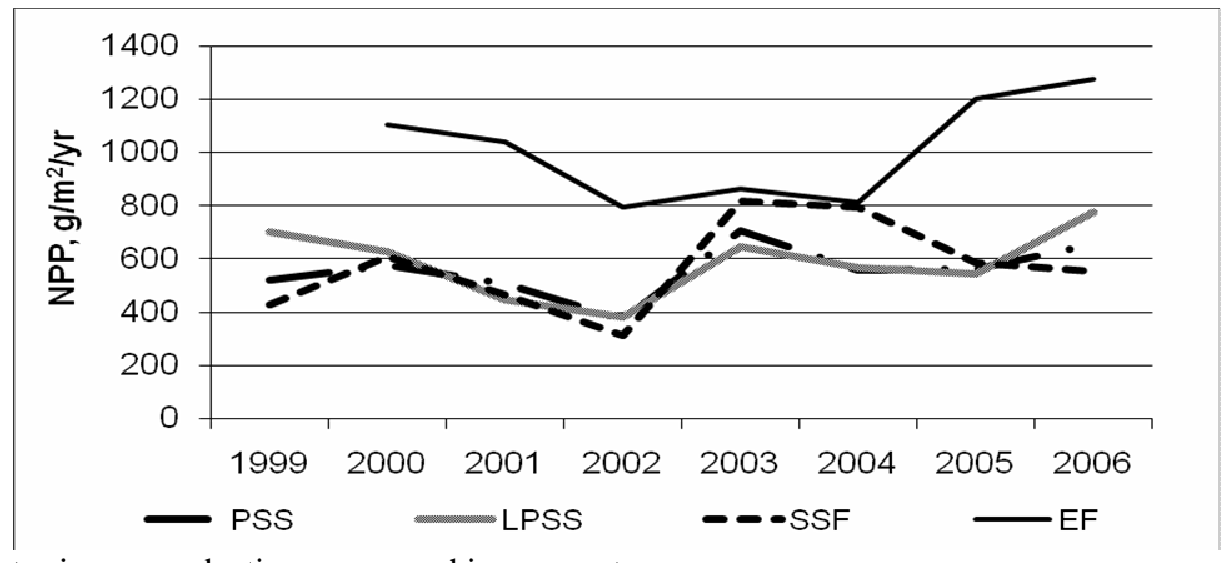

Fig.6. Dynamics of net primary production on researching ecosystems.

Puc.6. Динамика чистой первичной продукции в исследуемых болотных экосистемах. 
The correlation analysis has shown that the hydrothermal coefficient (HTC) have the most strong influence on production of LPSS $(r=-0.84)$ and PSS $(r=-0.53)$. NPP of PSS and SSF depend on the air temperature during the vegetation period. Precipitation has influence on productivity at LPSS. Studying of correlation between NPP and WTL has shown that WTL influences on productivity of LPSS (Table 3).

Table 3. Correlation coefficients between meteorological parameters and NPP at different peatland ecosystems. Таблица 3. Коэффициенты корреляции между метеорологическими параметрами и NPP болотных экосистем.

\begin{tabular}{|c|c|c|c|c|}
\hline & $\boldsymbol{P S S}$ & $\boldsymbol{L P S S}$ & $\boldsymbol{S S F}$ & $\boldsymbol{E F}$ \\
\hline Air temperature & 0.64 & - & 0.69 & - \\
\hline Precipitation & -0.59 & -0.88 & - & -0.61 \\
\hline HTC & -0.53 & -0.84 & - & -0.44 \\
\hline WTL & - & -0.74 & - & - \\
\hline
\end{tabular}

The detailed analysis of production of herbs, mosses and shrubs has shown that WTL affect at production of individual fractions. Positive dependencies between WTL and production of mosses $(r=0.62)$ and negative correlation with herbs production (-0.70) were revealed for PSS. Relationship between WTL and production of mosses has negative character for LPSS. WTL influences on production of mosses and shrubs at SSF. For EF relation between WTL and production of herbs was founded.

\section{CONCLUSIONS}

The main findings of this study can be stated as follows:

1. The storages of phytomass at different ecosystems of oligotrophic bog have similar values. Storages of phytomass at eutrophic peatland are 2 times higher in comparison to oligotrophic bog. The qualitative composition of phytomass depends on vegetation of the studied ecosystems.

2. The dynamics of phytomass growth depends on precipitation, air temperature, and water table level.

3. Net primary production at different oligotrophic ecosystems has close values. NPP at eutrophic peatland is 1.7 times higher in comparison to oligotrophic bog. The major part of production is provided by mosses and plant roots.

4. Dynamics of net primary production is defined by weather condition (air temperature and precipitation).

\section{REFERENCES}

Billings W.D., Luken J.O., Mortensen D.A., Peterson K.M. 1982. Arctic tundra: A source or sink for atmospheric carbon dioxide in a changing environment? // Ecologia. 53. P 7- 11.

Birukova O.N., Orlov D.S. 1995. Stocks of carbon of organic compounds in soils of the Russian Federation. Eurasian Soil Sci. № 1. P..21-32.

Botch M.S., Kobak K.I., Vinson T.S., Kolchugina T.P. 1995. Carbon pools and accumulation in peatlands of the former Sovet Union // Global Biogeochem Cycles. 9(1). P.37-46.

Carroll P., Crill P. 1997. Carbon balance for a temperate poor fen // Global Biogeochem Cycles. 11(3). P.349-356.

Cherepanov S.K. 1995. Vascular plants of Russia and adjacent states (the former USSR). Sankt-Peterburg. 990 p.

Chramov A.A., Valutskii V.I. 1977. Forest and bog phytocenosis of East Vasuganiya.-Novosibirsk. Nauka. 219 p. (in Russian)

Efremov S.P., Efremova T.T. 2007. Experimental diagnostics of peat accumulation and transformation of organic matter in bogforest ecosystems of Western Siberia // West Siberian peatlands and Carbon Cycle Past and Present. Proc of the Second Int Field Symposium. P.95-97. (in Russian).

Efremova T.T., Efremov S.P., Kosych N.P., Mironycheva-Tokareva N.P., Titlyanova A.A. 1994. Biological productivity and soils of bogs at south Vasuganiya // Siberian Journal of Ecology. 3. P.253-267 (in Russian).

Efremov S.P., Efremova T.T., Melent'eva N.V. 1994. Carbon stocks in bog ecosystems // Carbon in ecosystems of forest and swamps of Russia. Edited by V.A. Alekseev and P.A.Berdsi - Krasnoyarsk, P. 128-139.(in Russian).

Golovatskaya E.A., Porokhina E.V. 2005. Botany with Fundamental Phytocoenology. Biologic Productivity of Bog Biogeocoenoses: A Handbook. TGPU, Tomsk. 64p. (in Russian).

Gorham E. 1991. Northern Peatlands: role in carbon cycle and probable responses to climatic warming // Ecol. Applic. 1(2). P.182-195

Ignatov M.S., Afonina O.M.1992. Check-list of mosses of the former USSR // Arctoa. Vol. 1 (1-2). P. 1-85.

Kim J., Verma S.B. 1992. Soil surface $\mathrm{CO}_{2}$ flux in a Minnesota peatland // Biogeochem. 18. P.37-51.

Klinger L.F., Zimmermann P.R., Greenberg J.P., Heidt L.E., Guenther A.B. 1994. Carbon trace gas fluxes along a successional gradient in the Hudson Bay Lowlands // J. Geophys. Res. 99. P.1469-1494.

Moore T.R., Bubier J.L., Frolking S.E., Lafleur P.M., Roulet N.T. 2002. Plant biomass and production and $\mathrm{CO}_{2}$ exchange in an ombrotrophic bog // J. of Ecology. 90. P.25-36.

Moore T.R., Knowles R. 1989. The influence of water table levels on methane and carbon dioxide emissions from peatland soils // Can. J. Soil Sci. 69. P.33-38.

Neumann H.H., Hartog G., King K.M., Chipanshi A.C. 1994. Carbon dioxide flux over a raised open bog at the Kinosheo Lake tower site during the Northern Wetlands Study (NOWES) // J Geophys. Res. 99(D1). P.1529-1538.

P'yavchenko N.I. 1967. On the productivity of bogs of Western Siberia // Rastitelnye resursy. 3(4). P. 523-532. (in Russian). 
Sheng Y., Smith L.C., MacDonald G.M., Kremenetski K.V., Frey K.E., Velichko A.A., Lee M., Beilman D.W. and Dubinin P. 2004. A high-resolution GIS-based inventory of the west Siberian peat carbon pool // Global Biogeochem. Cycles. 18: GB3004.

Silvola J., Alm J., Ahlholm U., Nykanen H., Martikainen P.J. 1996. $\mathrm{CO}_{2}$ fluxes from peat in boreal mires under varying temperature and moisture conditions. J of Ecology 84:219-228.

Szumigalski A.R., Bayley S.E. 1997. Net aboveground primary production along a peatland gradient in central Alberta in relation to environmental factors // Ecoscience. 4. P.385-393. Russian).

The Great Vasyugan Bog. Current State and Evolution Processes. 2002. ed. by Kabanov MV, IOA SO RAN, Tomsk. 230 p. (in

Titlyanova A.A.1988. Biological Productivity of Grass Ecosystems.Novosibirsk.Nauka. 131 p. (in Russian).

Titlyanova A.A., Bulavko G.I., Kudryashova S.Ya., Naumov A.V., Smirnov V.V., Tanasienko A.A. 1998. Storages and losses of organic carbon in Siberian soils // Eurasian Soil Sci. 1.P.51-59. (in Russian). Russian).

Valutskii V.I., Chramov A.A. 1976. Theory and practice of forest telmathology and forest reclamation, Krasnoyarsk. P.59-82. (in

Vomperskii S.E. 1994. Peatlands role in the carbon cycle. Biogeocenotic features of peatlands and their rational use. Nauka, Moscow. P.5-73.(in Russian).

Vomperskii S.E.. Cyganova O.P., Kovalev A.G., Gluchova T.V., Valyaeva N.A. 1999. Waterlogged of territory of Russia as the factor of fixing of atmospheric carbon. Carbon cycle in territory of Russia. Moskow. P.124-146.

\section{БИОЛОГИЧЕСКАЯ ПРОДУКТИВНОСТЬ ОЛИГОТРОФНЫХ И ЭВТРОФНЫХ БОЛОТ ЮЖНОЙ ТАЙГИ ЗАПАДНОЙ СИБИРИ}

\section{Головацкая E.A.}

Приводятся данные многолетних (1999-2006 гг.) измерений запасов биомассы, динамики прироста фитомассы и мортмассы, чистой первичной продукиии (NPP) болотных биогеоченозов олиготрофного и эвтрофного типа, расположенных на территории южно-таежной подзоны Западной Сибири (Томская область). Выявлено, что запасы фитомассы и NPP эвтрофного болота почти в два раза выше по сравнению с олиготрофным. Динамика запасов фитомассы и мортмассы определяется видовым составом растительного покрова, трофностью местообитания и гидротермическими условиями.

Поступила в редакцию: 03.11.2010 Переработанный вариант: 13.12.2011 